\title{
WAKAF NON MUSLIM DAN WAKAF UANG MENURUT PANDANGAN WAHBAH ZUHAILI
}

\author{
Fitra Rizal \\ Institut Agama Islam Negeri Ponorogo \\ Email :fitrajal@gmail.com
}

\begin{abstract}
Islam presents itself as a philanthropic-faced religion, by realizing social security for the community to achieve a noble life. With the current development, it is important to bring up various challenges related to waqf law in Islam, specifically endowments, non-Muslims, and endowments of money. This article provides an explanation of how non-Muslim endowments and money waqf in Islam. According to Wahbah Zuhaili, Waqf from non-Muslims is permitted. Like in the activities of building mosques, schools and other facilities, both money, building materials and energy used for the construction. Donations or assistance are permitted, with conditions not binding and will not cause danger or slander in the future, both for Muslims and for supported institutions. According to Wahbah Zuhaili, waqf money is permissible. The Hanafi school that allows money waqf. For the reason of Istihsan bi al-Arabi, because many people have done it. In this regard, Wahbah Zuhaili states, in al-Fiqh alIslamiy wa ill Adillatuhu, what is meant is generally as follows, "Mutaqodimiin of the Hanafi School allows waqf money and dinars".
\end{abstract}

Keywords: Wahbah Zuhaili; Non-Muslim Endowments, Endowments Money.

Abstrak : Islam menampilkan dirinya sebagai agama yang berwajah filantropis, dengan mewujudkan jaminan sosial bagi masyarakat untuk mencapai kehidupan yang mulia. Dengan perkembangan zaman saat ini tentunya memunculkan berbagai tantangan terkait hukum wakaf dalam Islam, khususnya wakaf non Muslim dan wakaf uang. Artikel ini memberikan penjelasan terkait bagaimana hukum wakaf non Muslim dan Wakaf uang dalam Islam. Menurut Wahbah Zuhaili, Wakaf dari non Muslim diperbolehkan. Seperti dalam kegiatan pembangunan masjid, sekolahan dan sarana lainya, baik berupa uang, bahan bangunan maupun tenaga yang dimanfaatkan untuk pembangunan tersebut. Sumbangan atau bantuan tersebut diperbolehkan, dengan syarat tidak mengikat dan tidak akan menimbulkan bahaya atau fitnah dikemudian hari, baik bagi umat Islam maupun bagi lembaga yang bersangkutan.Menurut Wahbah Zuhaili, wakaf uang diperbolehkan. Hal tersebut didasarkan kepada pendapat Mazhab Hanafi yang membolehkan wakaf uang. Dengan alasan Istihsan bi al-'Urfi, karena sudah banyak dilakukan masyarakat. Berkaitan dengan hal tersebut, Wahbah Zuhaili menyatakan, dalam al-Fiqh al-Islamiy wa 'Adillatuhu, yang artinya secara umum adalah sebagi berikut, "Mutaqodimiin dari Mazhab Hanafi membolehkan wakaf uang dan dinar".

Kata Kunci: Wahbah Zuhaili; Wakaf non Muslim; Wakaf Uang

\section{A. PENDAHULUAN}

Dalam sejarah Hukum Islam, wakaf disyariatkan oleh Allah. melalui Nabi Muhammad kepada Umar Ibn Khattab. Umarlah yang kemudian pertama kali mewakafkan tanah di Khaibar, yang kemudian tercatat sebagai tindakan wakaf. Berpijak dari realitas normatif dan historis inilah kemudian, sebagian ulama' memformulasikan konsep wakaf yaitu dengan "penahanan harta benda yang memiliki daya tahan lama dan dapat dimanfaatkan untuk kepentingan yang diperbolehkan atau untuk kepentingan kebaikan dengan tujuan karena ingin mendekatkan diri kepada Allah dengan cara melepas hak pemakaian dari wakif sehingga tidak lagi menjadi miliknya dan kemudian menjadi milik Allah. ${ }^{1}$

1 Musthafa, "Aplikasi metode Pembaruan Hukum Islam Dalam Undang-Undang Nomor 41 Tahun 2004 Tentang Wakaf', jurnal Risalah Hukum Fakultas Hukum Universitas Mulawarman Samarinda Kalimantan Timur, Vol. 9, No. 1, Juni 2013, hlm. 61 
Islam menampilkan dirinya sebagai agama yang berwajah filantropis, dengan mewujudkan jaminan sosial bagi masyarakat untuk mencapai kehidupan yang mulia. ${ }^{2}$ Wujud filantropi digali dari doktrin keagamaan yang bersumber dari al-Qur'an dan Hadits yang dimodifikasi dengan perantara mekanisme ijtihad sehingga institusi zakat, infak, sadakah, dan wakaf terus berkembang. Wakaf terus mengalami perkembangan paradigma yang cukup signifikan seiring dengan penyesuaian berbagai aturan yang bersifat ijtihadi. Wakaf merupakan instrumen maliyah yang bersifat sakral dan suci, tetapi pemahaman dan implementasi wakaf tersebut tergolong pada fiqh (upaya yang bersifat kemanusiaan). Karena itu, bisa dipahami bahwa praktik dan realisasi wakaf tersebut selau berkaitan dengan realitas dan kepentingan umat di masing-masing negara muslim, termasuk Indonesia. ${ }^{3}$

Para Ulama Fiqh berbeda pendapat dalam menafsirkan makna wakaf, akan tetapi secara umum makna wakaf dapat dipahami sebagai menahan dzatnya benda dan memanfaatkan hasilnya atau menahan dzatnya dan menyedekahkan

2 Wahbah Zuhaili, Al-Quran Paradigma Hokum Dan Peradaban, ter. M. Luqman Hakiem Dan M. Fuad Harari (Surabaya: Risalah Gusti, 1996), hlm. 97

Ali Amin Isfandiar, "Tinjauan Fiqh Muamalat dan Hukum Nasional tentang Wakaf di Indonesia", Jurnal Ekonomi Islam La Riba UII, Vol. II, No. 1, Juli 2008, hlm. 52 manfaatnya. Menurut Wahbah, bahwa perbedaan pendapat para ulama fiqh dalam mendefinisikan wakaf diakibatkan oleh cara penafsiran yang berbeda dalam memandang hakikat wakaf. ${ }^{4}$ Hal tersebut terjadi karena terjadi perbedaan pemikiran dan akal manusia dalam memahami nash, dalam mengistimbathkan hokum dan dalam mengetahui rahasia-rahasia tasyri' serta 'illat hukum syariah.

Di beberapa negara, wakaf secara serius dijadikan sebagai media untuk mensejahterakan rakyat di samping pendapatan negara yang lain. Kekekalan objek wakaf menjadi salah satu doktrin utama untuk melestarikan keberadaannya. Selanjutnya modifikasi pemanfaat harta wakaf yang bervariasi menjadi inovasi pemberdayaan harta wakaf sehingga tidak statis dan stagnan. ${ }^{6}$ Wakif mengalami perubahan bentuknya, tidak hanya wakif perorangan tetapi juga wakif lembaga. Demikian pula dengan keberadaan nadzir yang profesional menjadi pilihan pada zaman modern sekarang ini, sehingga diharapkan harta

4 Wahbah Zuhaili, Al-Fiqh al-Islamiy wa 'Adillatuhu Juz 8 (Damsyiq: Dar al-Fikr, 1985), hlm.153

${ }^{5}$ Wahbah Zuhaili, Zakat Kajian Berbagai Mazhab, ter. Agus Effendi Dan Bahruddin Fananny (Bandung: Remaja Rosdakarya, 2008), hlm. 75

Ali Amin Isfandiar, "Tinjauan Fiqh Muamalat dan Hukum Nasional tentang Wakaf di Indonesia", hlm. 52 
wakaf dapat dikembangkan secara optimal.

Berdasarkan uraian diatas, sudah jelas bahwa keberadaan wakaf sangat penting bagi pemberdayaan masyarakat, karena memiliki cakupan manfaat yang sangat luas. Berdasarkan besarnya manfaat wakaf dan adanya nuansa ijtihadi dalam ruang lingkupnya, maka dalam artikel ini mencoba fokus membahas bagaimana wakaf non Muslim dan wakaf uang Menurut Pandangan Wahbah Zuhaili.

\section{B. LANDASAN TEORI}

\section{Mengenal Wahbah Zuhaili}

Wahbah Zuhaili adalah seorang ulama fikih kontemporer kelas dunia. Pemikiran fiqihnya menyebar ke seluruh dunia Islam melalui kitabkitab fiqihnya, terutama kitabnya yang berjudul al-Fikih al-Islami wa Adillatuh. Ia dilahirkan di desa Dir Athiyah, daerah Qalmun, Damsyiq, Syria pada 6 Maret 1932 M dan meninggal pada hari satu tanggal 8 Agustus 2015 dengan usia 83 tahun. Bapaknya bernama Musthafa azZuhili yang merupakan seorang yang terkenal dengan kesalihan dan ketaqwaannya serta hafi al Qur'an, dan bekerja sebagai petani dan senantiasa mendorong putranya untuk menuntut ilmu. ${ }^{7}$ ia mendapat pendidikan dasar di desanya, Pada tahun 1946, pada tingkat menengah beliau masuk pada jurusan Syari'ah di Damsyiq selama 6 tahun hingga pada tahun 1952 mendapat ijazah menengahnya, yang dijadikan modal awal dia masuk pada Fakultas Syariah dan Bahasa Arab di Azhar dan Fakultas Syari'ah di Universitas 'Ain Syam dalam waktu yang bersamaan. ${ }^{8}$

Ketika itu ia memperoleh tiga Ijazah antara lain, Ijazah B.A dari fakultas Syariah Universitas al-Azhar pada tahun 1956, Ijazah Takhasus Pendidikan dari Fakultas Bahasa Arab Universitas al-Azhar pada tahun 1957 dan Ijazah B.A dari Fakultas Syari'ah Universitas 'Ain Syam pada tahun 1957. Dalam masa lima tahun beliau mendapatkan tiga ijazah yang kemudian diteruskan ke tingkat pasca sarjana di Universitas Kairo yang ditempuh selama dua tahun dan memperoleh gelar M.A dengan tesis berjudul “az-Zira'i fi as-Siyasah asySyar'iyyah wa al-Fikih al-Islami”. Kemudian ia melanjutkan ke program doktoral yang diselesaikannya pada tahun 1963 dengan judul disertasi

${ }^{7}$ Saiful Amin Ghofur, Profil Para Mufasir al-Qur'an (Yogyakarta: Pustaka Insan Madani, 2008), hlm. 174

8 Muhammad Hasdin Has, Metodologi Tafsir Al-Munir Karya Wahbah Zuhaily, Al-Munzir Vol. 7, No. 2, (November 2014), hlm. 43-48 
"A ar al- arb fi al-Fiqih al-Isalmi" di bawah bimbingan Dr. Muhammad Salam Madkur. ${ }^{9}$

Pada tahun 1963 M, ia diangkat sebagai dosen di fakultas Syari'ah Universitas Damaskus dan secara berturut-turut menjadi Wakil Dekan, kemudian Dekan dan Ketua Jurusan Fiqih Islami wa Ma ahabih di fakultas yang sama. Ia mengabdi selama lebih dari tujuh tahun dan dikenal alim dalam bidang Fiqih, Tafsir dan

Dirasah Islamiyyah. Kemudian beliau menjadi asisten dosen pada tahun 1969 M dan menjadi profesor pada tahun $1975 \mathrm{M}$.

Sebagai guru besar, ia menjadi dosen tamu pada sejumlah univesritas di negara-negara Arab, seperti pada Fakultas Syariah dan Hukum serta Fakultas Adab Pascasarjana Universitas Benghazi, Libya; pada Universitas Khurtum, Universitas Ummu Darman, Universitas Afrika yang ketiganya berada di Sudan. Dia juga pernah mengajar pada Universitas Emirat Arab. Dia juga menghadiri berbagai seminar internasional dan mempresentasikan makalah dalam berbagai forum ilmiah di negaranegara Arab termasuk di Malaysia dan

9 Baihaki, "Studi Kitab Tafsir al-Munir Karya Wahbah Al-Zuhaili dan Contoh Penafsirannya Tentang Pernikahan Beda Agama", Jurnal Analisis, Vol. XVI, No. 1 (Juni 2016), hlm. 129
Indonesia.Wahbah Zuhaili menulis buku, buletin dan artikel tentang berbagai disiplin ilmu keislaman. Buku-bukunya melebihi 133 buah buku dan jika dikumpulkan dengan risalah-risalah kecil melebihi lebih 500 judul. $^{10}$

Ia sendiri dibesarkan di lingkungan ulama-ulama Mazhab Hanafi, yang membentuk pemikirannya dalam mazhab fiqih. Walaupun bermazhab Hanafi, namun dalam pengembangan dakwahnya ia tidak mengedepankan mazhab atau aliran yang dianutnya. tetap bersikap netral dan proporsional dan senantiasa menghargai pendapat-pendapat mazhab lain. Hal ini, dapat dilihat dari bentuk penafsirannya ketika mengupas ayat-ayat yang berkaitan dengan fiqh. Dalam pekembangannya, ia tampil sebagai salah satu pakar perbandingan mazhab. Salah satu magnum opus-nya, al-Fiqh al-Islami wa Adillatuhu, merupakan salah satu karya fiqih komparatif yang popular di masa ini. Ia menghembuskan nafas terakhir pada malam Sabtu, 8 Agustus 2015 pada usia 83 tahun. $^{11}$

Mayoritas karyanya mencakup bidang Fiqh dan Tafsir, berikut ini

\footnotetext{
${ }^{10}$ https:wikipedia.org/Wahbah_alZuhaili

11 Baihaki, "Studi Kitab Tafsir al-Munir Karya Wahbah Al-Zuhaili dan Contoh Penafsirannya Tentang Pernikahan Beda Agama”, hlm. 130
} 
beberapa karya Wahbah Zuhaili antara lain adalah sebagai berikut: 1) Athar Al-Harb Fi Al-Fiqh Al-Islami: Dirasah Muqarin; 2) Al-Fiqh AlIslami Wa Adillatuh; 3) Usul Al-Fiqh Al-Islami; 4) Al-Fiqh Al-Shafi'i AlMuyassar; 5) Al-Figh Al-Islami `Ala Madhhab Al-Maliki; 6) Financial Transactions In Islamic Jurisprudence; 7) Al-'Alaqat AlDawali Fi Al-Islam; 8) Al-Huquq AlInsan Fi Al-Fiqh Al-Islami Bi AlIshtirak Ma`Al-Akhireen; 9) Al-Islam Din Shura Wa Dimuqratiyah; 10) Haqq Al-Huriyah Fi Al-'Alam; 11) Asl Muqaranit Al-Adyan; 12) Al-`Uqud Al-Musama Fi Al-Qanun AlMu`Amilat Al-Madani Al-Emirati; 13) Tafsir Al-Munir ${ }^{12}$

\section{Teori Wakaf}

a. Pengetian Wakaf

Kata wakaf atau waqf ( الوقف ) berasal dari bahasa Arab yang berasal dari akar kata wa-qa-fa ( berarti menahan, berhenti, diam di tempat atau berdiri. Kata waqafa-yaqifu-waqfan semakna dengan kata habasa-yahbisutahbisan maknanya terhalang untuk menggunakan. Kata waqf dalam bahasa Arab mengandung makna

12 Muhsin Mahfudz , "Konstruksi Tafsir Abad 20 M/14 H (Kasus Tafsir al-Munir Karya Wahbah al-Zuhailiy)", Jurnal al-Fikr, vol. 14, no. 1, (2010), hlm. 34 menahan, menahan harta untuk diwakafkan, tidak dipindah milikkan. ${ }^{13}$

Para ulama fiqh berbeda pendapat dalam penafsiran makana wakaf, akan tetapi secara umum makna wakaf dapat dipahami sebagai menahan dzatnya benda dan memanfaatkan hasilnya atau menahan dzatnya dan menyedekahkan manfaatnya. Menurut Wahbah, perbedaan tersebut terjadi karena perbedaan mereka dalam memandang hakikat wakaf. Perbedaan pendangan tersebut dapat diuraikan sebagai berikut. $^{14}$

1) Abu Hanifah

Wakaf adalah menahan suatu benda dengan memberikan legalitas hukum kepada kepemilikan wakif dan menyedekahkan manfaat harta tersebut untuk kebajikan. Berdasarkan definisi itu maka pemilikan harta wakaf tidak lepas dari si wakif, bahkan ia boleh menariknya kembali dan ia boleh menjualnya. Jika si wakif wafat, harta tersebut menjadi harta warisan buat ahli

13 Wahbah Zuhaili, Al-Fiqh al-Islamiy wa 'Adillatuhu Juz 8 (Damsyiq: Dar al-Fikr, 1985), hlm.153

${ }^{14}$ Ibid, hlm. 153-155 
warisnya. Jadi yang timbul dari

wakaf hanyalah "menyumbangkan manfaat". Karena menurut Abu Hanifah bahwa wakaf bersifat sementara sehingga wakif suatu saat menguasai kembali barang yang diwakafkan. Oleh karena itu, dalam hal ini wakaf mirip transaksi pinjam-meminjam ('ariyah) karena pada dasarnya wakaf adalah menahan harta atas kepemilikannya dan mentasarufkan manfaat dari harta tersebut. ${ }^{15}$

\section{2) Madzhab Maliki}

Madzhab Maliki berpendapat
bahwa wakaf itu tidak
melepaskan harta yang
diwakafkan dari kepemilikan
wakif, namun wakaf tersebut
mencegah wakif melakukan
tindakan yang dapat melepaskan
kepemilikannya atas harta
tersebut kepada yang lain dan
wakif berkewajiban
menyedekahkan manfaatnya
serta tidak boleh menarik
hartanya untuk digunakan oleh
mustahiq (penerima wakaf),
walaupun yang dimilikinya itu

15 Miftahul Huda, Pengaliran Manfaat Wakaf Potret Perkembangan Hukum dan Tata Kelola Wakaf Di Indonesia (Bekasi: Gramata Publishing, 2015), hlm. 67 berbentuk upah, atau menjadikan hasilnya untuk dapat digunakan seperti mewakafkan uang. Wakaf dilakukan dengan mengucapkan lafadz wakaf untuk masa tertentu sesuai dengan keinginan pemilik. Dengan kata lain, pemilik harta menahan benda itu dari penggunaan secara kepemilikan, tetapi membolehkan pemanfaatan hasilnya untuk tujuan kebajikan, yaitu pemberian manfaat benda secara wajar sedang benda itu tetap milik si wakif. Perwakafan itu berlaku untuk suatu masa tertentu, dan karenanya tidak boleh disyaratkan sebagai wakaf kekal (selamanya).

3) Madzhab Syafi'iyah, Hanbaliyah dan sebagian Hanafiyah Madzhab ini berpendapat bahwa wakaf adalah mendayagunakan harta untuk diambil manfaatnya dengan mempertahankan dzatnya benda tersebut dan memutus hak wakif untuk mendayagunakan harta tersebut. Wakif tidak boleh melakukan apapun terhadap harta yang diwakafkan. Berubahnya status kepemilikan dari milik seseorang, kemudian 
diwakafkan menjadi milik Allah.

Jika wakif wafat, harta yang diwakafkan tersebut tidak dapat diwarisi oleh ahli waris. Wakif menyalurkan manfaat harta yang diwakafkannya kepada mauquf 'alaih (orang yang diberi wakaf) sebagai sedekah yang mengikat, di mana wakif tidak dapat melarang menyalurkan sumbangannya tersebut. Apabila wakif melarangnya, maka qadhi berhak memaksanya agar memberikannya kepada mauquf 'alaih. Karena itu madzhab ini mendefinisikan wakaf adalah tidak melakukan suatu tindakan atas suatu benda, yang berstatus sebagai milik Allah swt, dengan menyedekahkan manfaatnya kepada suatu kebajikan (sosial).

b. Dasar Hukum Wakaf

Menurut Wahbah Zuhaili dasar hukum wakaf adalah sebagai berikut: ${ }^{16}$

1) Wakaf dalam al-Quran

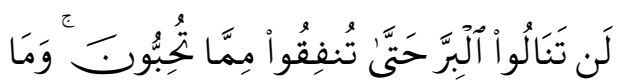

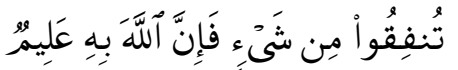

Artinya : Kamu sekali-kali tidak sampai kepada kebajikan (yang sempurna), sebelum kamu menafkahkan

16 Wahbah Zuhaili, Al-Fiqh al-Islamiy wa 'Adillatuhu Juz 8 (Damsyiq: Dar al-Fikr, 1985), hlm. 153 sebagian harta yang kamu cintai. dan apa saja yang kamu nafkahkan Maka Sesungguhnya Allah mengetahuinya (QS. AlImran: 92).
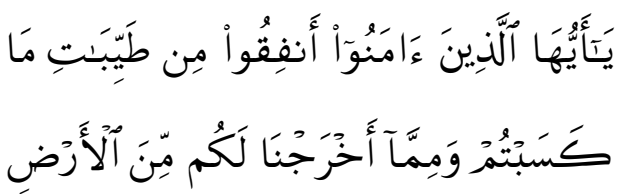

Artinya: Hai orang-orang yang beriman, nafkahkanlah (di jalan Allah) sebagian dari hasil usahamu yang baikbaik dan sebagian dari apa yang Kami keluarkan dari bumi untuk kamu (QS. AlBaqarah 276)

2) Wakaf dalam hadis

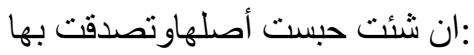

Artinya: Nabi bersabda: Bila kamu suka, kamu tahan pokoknya dan sedekahkan hasilnya.

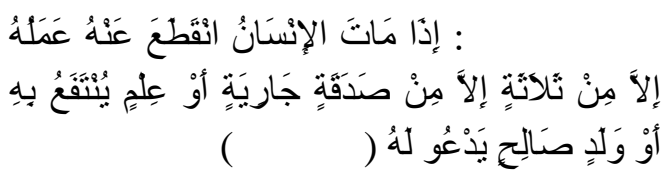

Artinya:Rasulullah bersabda: "Apabila manusia itu mati, terputuslah amalnya kecuali tiga perkara, yaitu shadaqah jariyah, ilmu yang dimanfaatkan, serta anak shaleh yang mendoakannya."(Diriwayat kan oleh Muslim).

3) Jenis Wakaf

Wakaf terbagi menjadi dua jenis, yaitu: wakaf kebajikan dan waka keluarga. ${ }^{17}$ Wakaf keluarga adalah wakaf yang manfaatnya 
diberikan kepada keturunan

wakif, seperti anak, cucu dan keturunannya. Sedangkan wakaf kebajikan adalah wakaf yang diberikan untuk amal kebajikan, seperti wakaf tanah untuk kegunaan rumah sakit atau sekolahan.

Wakaf kebajikan sangat dianjurkan dalam islam karena wakaf jenis ini ditujukan untuk kepentingan umum. Pahala wakaf kebajikan akan diterima terus oleh wakif walaupun ia sudah meninggal, karena harta wakafnya bisa dinikmati secara umum oleh masyarakat.

Sedangkan pada wakaf keluarga, biasanya penerima wakaf telah ditetapkan menurut ketentuan syarat yang dibuat wakif. Masalah yang mungkin timbul dari wakaf jenis ini adalah ketika anak, cucu atau keterunan wakif tidak mampu lagi memanfaatkan harta tersebut atau bahkan jika keluarga wakif terputus. Hal tersebut akan berdampak buruk bagi pengembangan wakaf.

4) Syarat Wakaf

Untuk kebaikan dan keafdhalan harta wakaf, maka wakaf harus memenuhi empat unsur sebagai berikut: Wakif atau orang yang berwakaf, harta yang diwakafkan, penerima wakaf (orang atau lembaga yang berhak menerima harta wakaf), Shigat, akad atau Ijab qabul (pernyataan wakaf dari pihak wakif kepada penerima wakaf). ${ }^{18}$

Untuk kebaikan dan keafdhalan harta wakaf, maka syarat seorang wakif adalah sebagai berikut: ${ }^{19}$

a) Wakif harus merdeka. Seorang wakif tidak boleh seorang budak, kemudian harta wakaf tersebut harus milik sendiri bukan hasil kejahatan.

b) Wakif haru sehat akalnya. Seorang wakif tidak beleh gila atau pikun.

c) Wakif harus sudah balig. Seorang wakif tidak boleh anak kecil (bayi).

Wakif harus bijaksana. Seorang wakif tidak dalam perwalian, kemauan sendiri, tidak dalam paksaan, tidak boleh seorang yang bangkrut, bodah dan ceroboh.

\footnotetext{
${ }^{18}$ Ibid, hlm. 176

${ }^{19}$ Ibid, hlm. 177
} 


\section{5) Harta Wakaf}

Syarat harta wakaf adalah sebagai berikut: ${ }^{20}$

a) Harta wakaf harus memiliki nilai (harga). Harta wakaf harus mengandung manfaat dan dapat dimanfaatkan. Maka harta wakaf yang tidak ada manfaatnya seperti barang-barang yang memabukkan dan apapun yang membahayakan atau menyesatkan dilarang oleh agama.

b) Harta wakaf harus jelas atau diketauhi. Harta wakaf harus jelas kepastiannya, dari segi jumlah, kadar, ukuran dan nilainya serta bukan harta yang bermasalah (sengketa).

c) Harta wakaf merupakan hak milik wakif. Harta yang ingin harus dimiliki secara penuh oleh wakif, bukan milik orang lain.

\section{6) Penerima Wakaf}

Penerima wakaf adalah orang yang menerima faedah atau manfaat dari harta wakaf tersebut. Penerima wakaf bisa berupa pihak tertentu atau pihak umum yang tidak tertentu seperti orang-orang miskin, para ulama, lembaga pendidikan atau tempat ibadah seperti masjid. Biasanya wakaf keluarga diberikan kepada pihak tertentu dan wakaf kebajikan diberikan kepada pihak umum. $^{21}$

7) Sighat, Akad Atau Ijab Qabul Dalam Wakaf

Sighat wakaf atau pernyataan wakaf dapat dikemukakan dengan tulisan, lisan atau dengan suatu isyarat yang dapat dipahami maksudnya. Dalam hal ikrar wakaf, redaksi yang digunakan lafaz-lafaz yang menunjukkan makna penahanan benda serta makna manfaat dari benda tersebut. Jika wakif menentukan pihak yang menerima wakaf atau wakaf diberikan kepada pihak tertentu maka menurut Hanafiyah dan Hambali wakaf tersebut tidak memerlukan lafad penerimaan, akan tetapi menurut syafii dan maliki wakaf tersebut harus memelukan lafad penerimaan. Berbeda dengan wakif yang tidak menentukan pihak penerimanya (diberikan kepada 
pihak umum) maka wakaf tidak memerlukan lafad penerimaan. ${ }^{22}$

\section{METODE PENELITIAN}

Penelitian ini merupakan penelitian literatur. Penelitian ini bersifat deskriptif kualitatif. Penulisan penelitian ini menggunakan metode deduktif.

\section{HASIL DAN PEMBAHASAN}

1. Wakaf Non Muslim Menurut Pandangan Wahbah Zuhaili Menurut Wahbah Zuhaili, Wakaf (sumbangan, bantuan) dari non Muslim diperbolehkan. Seperti dalam kegiatan pembangunan masjid, sekolahan dan sarana lainya, baik berupa uang, bahan bangunan maupun tenaga yang dimanfaatkan untuk pembangunan tersebut. Sumbangan atau bantuan tersebut diperbolehkan, dengan syarat tidak mengikat dan tidak akan menimbulkan bahaya atau fitnah dikemudian hari, baik bagi umat Islam maupun bagi lembaga yang bersangkutan.

Hal tersebut didasarkan kepada pernyataan wahbah zuhaili dalam kita tafsir al-Munir, yang artinya kurang lebih seperti berikut ini; "Menurut pendapat yang paling shahih bahwa orang kafir diperbolehkan membantu pembangunan masjid dan melakukan pekerjaan-pekerjaan yang terkait dengan pembangunan masjid seperti

\footnotetext{
${ }^{22}$ Ibid, hlm. 200
}

menjadi tukang batu dan tukang kayu. Karena hal ini tidak termasuk larangan yang disebutkan pada ayat di atas (at-Taubatayat 17-18). Akan tetapi, orang kafir tidak boleh menjadi pengurus masjid atau pengurus yayasan wakaf masjid. Namun, orang kafir diperbolehkan membangun masjid atau memberikan bantuan dana pembangunan masjid dengan syarat hal tersebut tidak akan menimbulkan bahaya (sengketa, fitnah). Jika hal di kemudian hari menimbulkan bahaya atau fitnah, maka hal tersebut dilarang. ${ }^{23} \mathrm{Hal}$ tersebut sebagaimana telah difirmankan dalam surat at-Taubah ayat $17-18$.

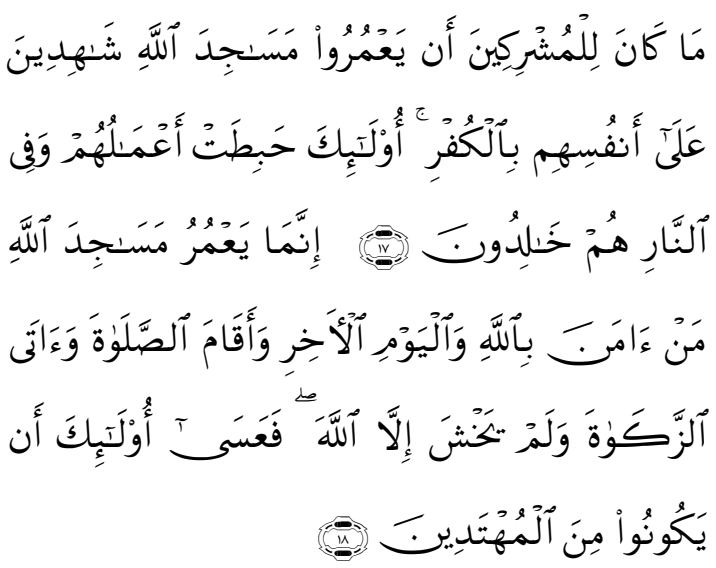

Artinya: Tidaklah pantas orang-orang musyrik itu memakmurkan mesjid-mesjid Allah, sedang mereka mengakui bahwa mereka sendiri kafir. Itulah orang-orang yang sia-sia pekerjaannya, dan mereka kekal di dalam neraka. Hanya yang memakmurkan

\footnotetext{
${ }^{23}$ Wahbah Zuhaili, Tafsir al-Munir Fii alAqidah Wa as-Syari'ah Wa al-Manhaj Juz 10 (Damsyiq: Dar al-Fikr, 2003), hlm. 499-489
} 
masjid-masjid Allah ialah

orang-orang yang beriman

kepada Allah dan hari

Kemudian, serta tetap

mendirikan shalat, emnunaikan

zakat dan tidak takut (kepada siapapun) selain kepada Allah, Maka merekalah orang-orang yang diharapkan Termasuk golongan orang-orang yang mendapat petunjuk (QS. atTaubah 17-18).

2. Wakaf Uang Menurut Pandangan Wahbah Zuhaili

Wakaf uang adalah wakaf yang dilakukan seseorang, kelompok orang, dan lembaga atau badan hukum dalam bentuk uang tunai. Hukum wakaf tunai telah menjadi perhatian para fuqaha'. Beberapa sumber menyebutkan bahwa wakaf uang telah dipraktikkan oleh masyarakat yang menganut mazhab Hanafi. Caranya ialah dengan menjadikan dinar dan dirham itu sebagai modal usaha, kemudian menyalurkan keuntungannya sebagai wakaf. $^{24}$

Menurut Wahbah Zuhaili, wakaf uang diperbolehkan. Hal tersebut didasarkan kepada pendapat Mazhab Hanafi yang membolehkan wakaf uang. Dengan alasan Istihsan bi al'Urfi, karena sudah banyak dilakukan masyarakat. Mazhab Hanafi berpendapat bahwa hukum yang ditetapkan berdasarkan 'urf (adat

\footnotetext{
${ }^{24}$ Kementrian Agama Republik Indonesia, Panduan Pengelolaan Wakaf Tunai, (Kemenag: 2013), hlm. 2
}

kebiasaan) mempunyai kekuatan yang sama dengan hukum yang ditetapkan berdasarkan nash (teks). Hal tersebut berdasarkan atsar Abdullah bin Mas'ud r.a yang artinya, "Apa yang dipandang baik oleh kaum muslimin maka dalam pandangan Allah adalah baik, dan apa yang dipandang buruk oleh kaum muslimin maka dalam pandangan Allah pun buruk". ${ }^{25}$ Berkaitan dengan hal tersebut, Wahbah Azuhaili menyatakan dalam Al-Figh al-Islamiy wa 'Adillatuhu, yang artinya secara umum adalah sebagi berikut,"Mutaqodimiin dari Mazhab Hanafi membolehkan wakaf uang dan dinar". ${ }^{26}$

\section{E. KESIMPULAN}

Menurut Wahbah Zuhaili, Wakaf dari non Muslim diperbolehkan. Seperti dalam kegiatan pembangunan masjid, sekolahan dan sarana lainya, baik berupa uang, bahan bangunan maupun tenaga yang dimanfaatkan untuk pembangunan tersebut. Sumbangan atau bantuan tersebut diperbolehkan, dengan syarat tidak mengikat dan tidak akan menimbulkan bahaya atau fitnah dikemudian hari, baik bagi umat Islam maupun bagi lembaga yang

${ }^{25}$ Kementrian Agama Republik Indonesia, Panduan Pengelolaan Wakaf Tunai, (Kemenag: 2013), hlm. 130

${ }^{26}$ Wahbah Zuhaili, Al-Figh al-Islamiy wa 'Adillatuhu Juz 8 (Damsyiq: Dar al-Fikr, 1985), hlm.162 
bersangkutan.Menurut Wahbah Zuhaili, wakaf uang diperbolehkan. Hal tersebut didasarkan kepada pendapat Mazhab Hanafi yang membolehkan wakaf uang. Dengan alasan Istihsan bi al-'Urfi, karena sudah banyak dilakukan masyarakat. Berkaitan dengan hal tersebut, Wahbah Zuhaili menyatakan, dalam Al-Fiqh al-Islamiy wa 'Adillatuhu, yang artinya secara umum adalah sebagi berikut,"Mutaqodimiin dari Mazhab Hanafi membolehkan wakaf uang dan dinar".

\section{DAFTAR PUSTAKA}

Baihaki. "Studi Kitab Tafsir al-Munir Karya Wahbah al-Zuhaili dan Contoh Penafsirannya Tentang Pernikahan Beda Agama”. Jurnal Analisis, vol. XVI, no. 1 (Juni 2016).

Ghofur, Saiful Amin. Profil Para Mufasir al-Qur'an. Yogyakarta: Pustaka Insan Madani, 2008.

Has, Muhammad Hasdin. "Metodologi Tafsir Al-Munir Karya Wahbah Zuhaily," Al-Munzir Vol. 7, No. 2, (November 2014).

Huda, Miftahul. Pengaliran Manfaat Wakaf Potret Perkembangan Hokum dan Tata Kelola Wakaf di Indonesia. Bekasi: Gramata Publishing. 2015.

Isfandiar, Ali Amin. "Tinjauan Fiqh Muamalat dan Hukum Nasional tentang Wakaf di Indonesia". Jurnal Ekonomi Islam La Riba UII, Vol. II, No. 1, (Juli 2008).

Kementrian Agama Republik Indonesia. Panduan Pengelolaan Wakaf Tunai. Kemenag: 2013.
Mahfudz, Muhsin. "Konstruksi Tafsir Abad 20 M/14 H (Kasus Tafsir al-Munir Karya Wahbah al-Zuhailiy)". Jurnal al-Fikr, vol. 14, no. 1, (2010)

Musthafa. "Aplikasi metode Pembaruan Hukum Islam Dalam Undang-Undang Nomor 41 Tahun 2004 Tentang Wakaf". Jurnal Risalah HUKUM Fakultas Hukum Universitas Mulawarman Samarinda Kalimantan Timur, Vol. 9, No. 1, (Juni 2013).

Zuhaili, Wahbah. Al-Fiqh al-Islamiy wa 'Adillatuhu Juz 8. Damsyiq: Dar alFikr. 1985.

- Tafsir al-Munir Fii al Aqidah Wa as-Syari'ah Wa al-Manhaj Juz 10. Damsyiq: Dar al-Fikr. 2003.

\section{Al-Quran Paradigma}

Hokum Dan Peradaban, ter. M. Luqman Hakiem Dan M. Fuad Harari. Surabaya: Risalah Gusti. 1996.

\section{Zakat Kajian Berbagai} Mazhab, ter. Agus Effendi dan Bahruddin Fananny. Bandung: Remaja Rosdakarya. 2008.

https:wikipedia.org/Wahbah_al-Zuhaili. 